\title{
MATTER

\section{Review of the book: New Directions in Philosophy and Literature (Rudrum, Askin, \& Beckman, 2019)}

\section{Mar Sureda Perelló \\ University of Barcelona}

\section{DOI: https://doi.org/10.1344/jnmr.v2i2.35902}

The intersections between reflexive and critical thinking and literature are both constant and changing. Literature is more than pleasure, distraction and leisure; literature gives us something to think, and to think about. Philosophy, on the other hand, aspires to conceive the literary fact from the strict discipline of the concept, to produce reason out of it emerging from an anthropocentric knowledge, as well as its natural and social insertions. Since Hegel and Romanticism, contemporary philosophy and thought have sought to understand literature as a form of consciousness that, with the aid of imagination, leads to human self-knowledge in both its individual and collective dimensions. The book contributes to new material relationships between literature and philosophy, both at the academic and political levels, in both disciplines. It also develops key notions about theory and practice, as well as theoretical and political discussions and debates between the different disciplines on contemporary theory.

New Directions in Philosophy and Literature is a book that explores intensively the turns and tensions that have constituted the crossroads between literature and philosophy. The book is an exhaustive work in which the reader can discover new perspectives and debates that are significant for literary studies, the theories of posthumanism and new materialisms. The editors David Rudrum, Ridvan Askin, and Frida Beckman aim at "hop[ing] that the collection succeeds in both acknowledging and encouraging new ways of configuring the relationships between literature and philosophy, broadly conceived." (p.1) 
The relationship between literature and philosophy starts with the origin of both disciplines themselves. From the transition from myth to logos to the current logical hegemonic of knowledge, literary studies and philosophy have remained close, but separate at the same time. Nevertheless, as David Rudrum writes "In the early twentyfirst century, however, debates around modernity, postmodernity, and postmodernism have subsided, and there seems to be a pervasive acceptance that the postmodern moment has come to an end" (p.19). For this reason, this book questions this relationship and proposes alternatives to think from multiple (others) perspectives. This book is an example of how new materialisms, post-humanism and speculative fiction, open multiple ways to rethink and represent the worlds, the fields, the stories and the words. It provides elastic possibilities for literature and philosophy.

The book is divided into six sections, preceded by a genealogical introduction written by Claire Colebrook. The different sections allow and invite the reader to discover tools and stories to recognize and promote new ways of shaping the relationships between literature and philosophy. These relationships are based on a transversal thread, a constant intra-action (Barad, 2007) established between both disciplines, which, far from perpetuating its distinctions, presents a field full of possibilities. As a starting point, the desire to conceptualise what comes "after" postmodernity is presented, as well as the meanings that surround the post-human, the new materialisms, the concept of the Anthropocene and biopolitical philosophy. In the introduction, Claire Colebrook presents the development of the parallel study of philosophy and literature that took place during the 20th century, and the point of view explored in the 19th century. She opens multiple narratives that move from the particular to the infinite, from the micro to the macro, from the multiple structures of functioning to the expansion of possibilities and tensions. As Colebrook explains:

Not only is philosophy never at peace with itself, philosophy's ongoing internal tension is bound up with its ongoing difference and complicity with literature. This is primarily because both literature and philosophy are bound up with a system of language that both enterprises seek to save from everyday banality for the sake of everyday richness. (p.4) 
It articulates its reflection around the continuous negotiation that exists between the representation of the forms of the world together with its own renewal. And it is precisely this negotiation that transcends the relationship between philosophy and literature.

To continue, in the first part, titled "Beyond the Postmodern: Literature, Philosophy, and the Question of the Contemporary" (p.19), the authors explore how the contribution between philosophical and literary perspectives analyses and dialogues with the particularities of the wake of postmodernism. The different chapters of this section reflect on the characteristics of this contemporaneity; as well as on the trends underlying current aesthetic issues, and on the task of finding a new name for the present. This section addresses the concerns that these limitations open up in the current debate on the potentialities of the non-human in literary construction.

A challenge within literary theory and philosophy would be, as explored in this volume, to admit that it is not necessary to limit the proliferation of narratives and theories that try to account for the world and its existence but to explore and recognize the intimate overlap between knowledge and creation. As explained in the editors' Preface "More traditional forms of analytic thought have been enriched as the insights of ordinary language philosophy have engaged in a dialogue with literary criticism, to the benefit of both disciplines" (p.1). Throughout the book, there are examples of how philosophy and literature do not stop sharing questions and concerns about the world we inhabit. After all, it is a matter of observing how literature provokes philosophy as much as it can become an object of fiction and literary creation.

The second and third parts raise the tensions and possibilities around two related displacements; a) the encounter between the human and the non-human, b) the object-oriented philosophy and different ways, to go beyond the subject. Along with the four chapters of the second part "Beyond the Subject: Posthuman and Nonhuman Literary Criticism" (p.99), we find a determination to theorise beyond human subjectivity. For example, in the first chapter in part 2 Brigit Mara Kaiser postulates how Cixous' post-structuralism marks the beginning of a turn towards the relationship between the material and the embodied, as well as in the encounter between human and non-human agents that would later be consolidated. She highlights precisely how, 
"Cixous's engagement with subjectivity debunks traditional Western humanist conceptions of the Subject that are based on human exceptionalism and rationality as its anchor-points" (Kaiser, p.104), and then rely on the entanglements of the affective, the immaterial and the non-human to trace different foundations instead.

The third part, "Beyond the Object: Reading Literature through Actor-Network Theory, Object-Oriented Philosophy, and the New Materialisms" (p.175), is an explanation of how these theories are used in the study of literature or how the study of literature can help to understand or even develop the theories themselves. All chapters in this section explore alternatives to the traditional subject-object binomial. They all examine how these alternatives are developed in conjunction with the many forms of literature. An example of this to be highlighted is the chapter "A Field of Heteronyms and Homonyms: New Materialism, Speculative Fabulation, and Wor(I)ding" by Helen Palmer (p. 215). The author gives us a new materialistic reading of speculative fiction, particularly recent Afrofuturist literature. Understanding and relating to the process of wor(I)ding "as a process of construction of the discursive-material world" (Haraway, 2016, p.13). It exposes the fundamental interweaving between matter, the discursive and the semiotic, dialoguing with Haraway and Barad. The author maps "The Field" as an unstable and enabling place (p.217). The Field is a challenge not only for literature or philosophy but also for research since it is articulated as an enabling space.

The turns, tensions and displacements that open up between and from philosophy and literature would not be entirely possible without rethinking the channel that transports them; language. The problem of words and things is the questioning of whether there is indeed a correspondence between things that are in themselves and how we name them.

There is a legitimate correspondence between words and things. This question is extensively articulated in the fourth part of the book titled "Ordinary Language Criticism: Reading Literature through Anglo-American Philosophy" (p.255). The authors address the question of how the critique of ordinary language is not a literary theory, but rather a style of thought, or a way of working with language and texts. This relationship with linguistics and the challenges of the new approaches to linguistic 
criticism allow for the exploration and creation of (literary) worlds in which to rethink the materialities, ethics and politics that take place in The Field.

The fifth part of the collection, entitled "The Incarnation as Ethics": Literature and Life in the Anthropocene" ( $p .317$ ) includes four chapters that explore the ethical and conceptual challenges of philosophy and literature in the Anthropocene era. Precisely, another valuable insight of this volume consists in how we relate to literature as a mode of research in itself. An investigation that is based on a political commitment. The concern for the destructive effect of the human species and the care of the environment (nature) is not new, nor in philosophy, nor literature. This section provides some brushstrokes in the construction of new ethics for new challenges (Haraway, 1988), and in this part, we find the contribution of Adrian Parr with "So to Speak" (p. 382). It is a fundamental and interesting contribution on how to denounce the injustices of the environmental crisis in an exclusively secular way. Poetically Parr reminds us of the need to continue exploring and investigating how literature allows us to rediscover and relate to each other in a changing world. This relates to the thesis of the last section of the volume "Politics after Discipline" (p.391). It begins with King Chow's contribution, where the author questions how literature is trapped in biopolitical conditioning, situating it as an academic field inseparable from the context of biopolitics, which also involves the university as an institution itself in the nonrenewal of language. Both the above mentioned and the contribution of other authors such as Frida Beckman (one of the editors) and Charlie Blake, represent an impeccable genealogy for analysis on how the political structures of control intrinsically affect the modes and topics of literature.

In conclusion, New Directions in Philosophy and Literature is an exhaustive work to situate necessary issues in the fields of philosophy and literary studies. It explores fundamental questions that have to do with epistemology and with the absolute and, at the same time, long-standing need for holistic and organized approaches to such a complex and difficult social context. In that sense, when the variety of events, processes and situations is so wide, only the theories that are capable of organizing a systemic and, at the same time, integrated vision, can be useful. After all, both, philosophy and literature, are attempts to understand a world whose meaning is not 
given to us beforehand. Yet we name things; we make theories and stories about reality without knowing for sure whether we are getting close to its "true" form, yet in the very act of naming it, it moves away just because it is named. The focus of the questions raised throughout the sections of this book is the idea that literature, philosophy, science and their multiple intersections generate thought using different tools and means that overlap.

\section{Bibliography}

Barad, Karen (2007). Meeting the Universe Halfway: Quantum Physics and the Entan glement of Matter and Meaning, Durham, NC: Duke University Press.

Haraway, Donna (1988). Situated Knowledges: The Science Question in Feminism and the Privilege of Partial Perspective. Feminist Studies, 14(3), 575-599.

Haraway, Donna (2016). Staying with the Trouble: Making Kin in the Chthulucene. Durham, NC: Duke University Press.

\section{Author Information}

\section{Mar Sureda Perelló (marpsureda@gmail.com)}

Mar Sureda Perelló is a museum education officer, arts educator and PhD candidate under the program Arts and Education of the University of Barcelona. She is a BA graduate in Fine Arts (University of Barcelona, Spain) and holds a Master's Degree in Visual Arts and Education (University of Barcelona, Spain). In her professional career, she has worked in several educational projects involving video, literature and arts. She has focused on the pedagogical potentialities of multiliteracy and visual arts, especially on how these can be a tool for enabling socially committed learning processes. In her thesis she seeks to approach the pedagogical and methodological possibilities that artistic practices offer in order to promote reading understood as a sociocultural practice in pedagogical contexts. She currently combines academic research with educational services department coordination at Barcelona Design Museum. 